\title{
A STUDY OF CAREER ADAPTABILITY AND CAREER PLANNING OF FACULTY OF EDUCATION STUDENTS OF UNIVERSITAS NEGERI MALANG
}

\author{
Muslihati $^{1}$ \\ Universitas Negeri Malang \\ Corresponding e-mail: muslihati.fip @um.ac.id
}

\begin{abstract}
This study aim to describe career adaptability and career planning of the students of faculty of education of Universitas Negeri Malang East Java Indonesia. Research conducted by mixed method adapted from Tasakkori model. Research population were fifth semester student of faculty of education. Research sample was token by cluster random sampling. Data collected by career adaptability inventory that include four domain are career concern, career control, career curiosity, and career confidence. Interview process is utilizing focus group discussion manual about career adaptability and career planning in Asean Economic Community Era. The study result indicates that most of student have level of career adaptability. They good in confidence but tend to lack of concern, control, curiosity toward their future career . Most of student try to plan their career in interpreunership work. The choice is their career planning priority besides educational service job. Most of student have two career planning after graduate from bachelor degree, but they feel hard to start their career. Research result implies on career guidance for university student for enhancing student career planning skills.
\end{abstract}

Keywords: career adaptability, career planning, work, job, career choice.

\section{INTRODUCTION}

Career guidance is aimed at helping students to understand and accept themselves as well as proficient in planning of his future. Through career guidance, counselors facilitate students gain independence in selecting and choose further study or enter the world of work. Ideally, career guidance services facilitate students meet the challenges of a career development tasks and present and future as well as skilled career planning. One of career guidance service is preparing career adaptability among the teenagers who will face the competition of work in the global context.

As the leaders of tomorrow, young people need career adaptability as well as career planning to succeed in global competition. According to Harkness (2008) good career planning help a person determine appropriate career choices to achieve career success and satisfaction. His suggestion to young people is starting their career planning early. This view supports the career theory of Super [1] that adolescents face exploration stage career and need help in fulfiling their career developmental task well. Young people need to be facilitated to for achiving their career adaptability. Fulfiling career exploration stage means understanding self traits, undertanding career information. Career planning, in support of future careers and skilled career planning so as to face the challenges of the current career and future. Herr et al., (2004) confirmed that teens who do not understand their own potential and lack of career information likely to have career problems and result in less achievement of success and career satisfaction. 
A prelimenary study found that some student have some problem related to their career development. They are lack of self-understanding, less career information, lack of skills in selecting career information, feel miscast major, lack of self confidence of their competence and feeling doubtful of their future. This condition would not support their competitiveness in the world of work and the business world.

Related to the student career problem, this study aims to describe the student's career adaptability Faculty of Education and their career planning for their future. This study refers to Savickas's theory which includes four aspects are concern for the career, career management or control, career opportunities, curiosity and careerconfidence. The advantages of this theory has been tested by [6] at the end of the adolescent respondents. While [5] studied career adabtability and career development of young people in Turkey.

Reviews of career adaptability should begin with the study of the nature of the career itself. One definition of a sufficiently comprehensive career forward by [2]. Jobs thinks is the journey of human life and efforts to meet development tasks in achieving the ideals and independence. Components within the meaning abour career aspirations according to Herr are include employment, utilization of free time or leisure, hobbies, lifestyle and environment are chosen as a residence. This definition makes career so complex and dynamic. The process is continuous throughout a person's life. On the other hand, it will be achieved through the specific requirements.

Referring to the view that the development of a person's career Super occurred since the beginning until the end of his life. Super [1] divides into five stages of career development. Career development starts from the development (growth) that have occurred since individuals are born until reaching the age of 14 years. At this time many learning experiences that will influence the ideals and aspirations of a career. Further development of the career switch into the career exploration period when the individual reaches the age of 15 years until he was 24tahun. At this time the identity of individuals seeking career and study the various alternatives that can be practiced. Future career development or build a career or establishment that occurs at age 25 to 44 years, a period of stabilization and maintenance career which occurs at the age 45 years to 64 years, and a period of decline that occurs at age 65 until death.

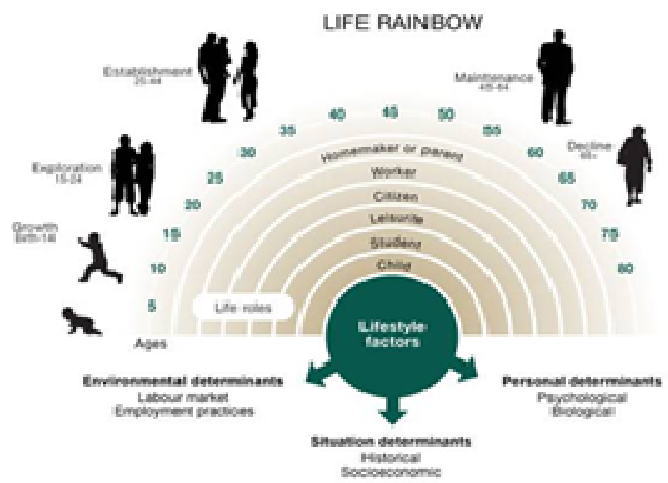

Figure 1. Super's career development

Based on career development stages in career rainbow, a teenager or high school students as a subject in this study are in the development stage of career exploration. This stage requires the guidance and support for the career exploration process is going well and become a solid foundation for the next stage of the establishment or development and career development.

An indicator of career development successful is the achievement of their career development career adaptability. This is related to career maturity concept by Donald E. Super 1950. [3] defines the adaptability of a career is "a psychosocial construct that denotes an individual's readiness and resources for coping with current and anticipated tasks, transitions, traumas in their occupational roles that, to some degree large or small, alter Reviews their social integration. Adaptability career is a constructs of psychosocial that illustrates the ability and readiness of individuals in facing and preparing their career succeed today and in the future as a part of career development, including the face and carry out the transition in the world of work as well as deal with and manage issues in the role and job duties in which they live, both issues small and simple to large and complex problem and cause traumatic effects. Savickas added that career adaptability required in social integration and achievement of the tasks of career development throughout the life span.

Career adaptability has four important aspects that are concern to the career, control and manage of career planning, career opportunities curiosity and career confidence. Career concern regarding to awareness of one's career his future as a professional [4]. Career concern also associated with long-term orientation and a feeling of optimism as workers. Low concern can lead to pessimism career will be successful in the future. Controlling career means that efforts to improve the self-management through decision-making and responsibility for the future. If the ability to control the career did not develop the 
potential to cause problems inability to take career decisions, and uncertainty of future career (Beran \& [5]. Curiosity on career opportunities also related on career curiosity thar expressed by understanding society dynamics and the latest information about careers. Career curiosity describe about curiosity in creating productive career and the opportunity to realistically explore the educational and occupational information in the future (Flum \& Blustein, 2000; Patton \& Porfeli, 2007). [6] [7] studied career adaptability related to career development of adolescents.

In the process of career exploration and career adaptability fulfill, teens need to be guided in the planning of a career that will help them find suitable career choice. Career planning is a dynamic process that adapt to changes in a person experiences formed over increasing professional knowledge or career competence, experience and self-identity. Planning and career development rests on the search or discovery of self (self-discovery) in which the individual is constantly continuously make efforts self-assessment process and testing the values of self (self-reflection), in this context occurs in the educational environment. In the process of career planning there are a number of sustainable activities in the form of self-understanding, understanding the environment and the world of work, decisionmaking and implementation. Career decisionmaking can be a big decision and or small decisions about jobs, education, hobbies and other life roles.

\section{METHOD}

In accordance with the purpose of this study was to describe the adaptability of career students of the Faculty of Education, this study design using a mixed method which refers to the procedure that was developed from Tashakkori and Teddlie (2003), with the design of the quantitative-qualitative sequential (the dominant method is quantitative equipped with qualitative methods).

Quantitative data about adaptability career of faculty of education student collected in the first step and following by collecting qualitative data that the opinions and views of students about the challenges of MEA and plan their careers after graduating from the educational process on departmentin the Faculty of Education.. Data both the views and opinions of students about the challenges of Asean Economic Society and plan their careers after graduating from the educational process on departmentin the Faculty of Education. The research subject are all the student of faculty of education that study in six courses are school guidance and counseling, educational technology, school management, Elementary and Preschool Teacher, Special Education. Collecting data in this study using the inventory career adaptability developed from theory Savickas (2001). Another instrument used is the interview about the global challenges of career adaptability of students. The instrument has been declared valid and reliable. Data analyzed by descriptive statistical data analysis techniques.

\section{RESULT AND DISCUSSION}

Research on career adaptability of Faculty of Education students performed at seven department that are Guidance and Counseling, Educational Technology, Special Education, school administration, Elementary Teacher and Early Childhood Education. The data was collected to profile four aspects of Career Adaptability concern for careers, self-control to achieve a future of hope, curiosity on the information and career opportunities, as well as the belief in success in the future.

The data descripted that some of faculty of education students $(59.79 \%)$ has middle level of adaptability career. If the assessed level of career adaptability of students every, it is known that students only study programs School Administration had a career high degree of adaptability that is 70,75 $\%$. The data mean that all student sequence are 62 , $75 \%$ guidance and counseling $(61.75 \%)$, non formal education $(60.75 \%)$, ET (58 \%), ES (54.25 $\%)$ and the lowest is non formal education (50.25\%). The results of the study at each study program indicates that student of guidance and counseling program has the level of concern (63\%), management $(62 \%)$, curiosity $(54 \%)$ of students in the medium category. But on the other hand, confidence will student career success at the high category $(68 \%)$. Student of non formal education on the level of concern (59\%), management $(66 \%)$, curiosity $(55 \%)$ and confidence $(63 \%)$ of students to careers in middle category. At ET Department student has middle level career concern (57\%), middle career control or management $(65 \%)$, middle level of career curiosity $(50 \%)$ and also in career confidence $(60 \%)$ of students to careers in middle category. Career adaptability profile of ET departmentstudent is, they has middle level of career concern (55\%), management (66\%), low level of career curiosity $(37 \%)$ and middle level of career confidence $(59 \%)$. Career adaptability profile of SA department student is their career awareness in in medium level (63\%), but the control (77\%), 
curiosity $(71 \%)$ and career confidence $(72 \%)$ of SA students are in high level. Career adaptability career profile of non formal education student are, the have low level of career concern (49\%), middle level of career management $(57 \%)$, low level of career curiosity $(43 \%)$ and middle level of career confidence (52\%). Average the students has middle category of career adaptability. Student of $\mathrm{KE}$ department as medium level of career concern (61 $\%)$, career curiosity (55\%) and career confidence $(60 \%)$ of students to careers in middle category. But the level of career control of KE student is high level (75\%). The data illustrate that the general level of adaptability career faculty of education students still in middle category, both in aspects of care, control, curiosity and confidence of students to careers.

Meanwhile, the distribution of the data was also categorized based on gender. This is to determine how is comparative overview about student's career adaptability level between male and female students. In general concern, curiosity and confidence careers of male students and female students tend to be similar, but the female students tend to have control of more career high (70\%) is at the high category, compared to male students (53\%) were middle category. Based on gender analysis, career adaptability of the student of ES course, control and assurance careers students of men and women tend to be similar, namely the category of being, but in the aspect of curiosity about career information, students ES male was lower, in the low category (29\%) compared with female students who have a curiosity with category. Levels of concern and curiosity among the students career men and women tend to be similar, namely the medium category, while the control, curiosity and conviction careers of male students tend to be lower than female students. While in KE that none of the student are male, the data just collected from female students.

Profil of career choice of faculty of education students $83 \%$ students are, the students of Elementary School Teacher department put jobs as teachers and educators as the first priority of his career choice, 5\% student want to become entrepreneurs, $12 \%$ student want to work as employees of company.

Career choice of guidance and counseling students illustrated as follows. $43 \%$ student wanted to be a counselor, $26 \%$ student want to build theie own business, $13 \%$ student want to be employee, 18 $\%$ student want to pursue a career in the field of fashion and art. Meanwhile, in the department of Special Education, as a career choice of priorities,
$84 \%$ of students choose a career in education, $16 \%$ student plan to work to be entrepreneur in various fields, especially children with special needs therapy services. As a second career choice, $42 \%$ student want to work in the field of education, $47 \%$ are planning to become entrepreneurs, $11 \%$ student want to be employees and freelance workers.

The profile of student career choice of elementary teacher department are $84 \%$ of students choose their career in educational field, $16 \%$ student plan to be an entrepreneur in various fields, especially children with special needs therapy services. Students career choices in Education Technology department is as follows. $28 \%$ student want to build their career in educational field, $28 \%$ student want to set up their own businesses in educational technology, $28 \%$ student would like to work in mass media such as television and broadcasting, $12 \%$ student want to be a civil servant in govermental services, and $4 \%$ student want to be employees of the company. In a second career plan of ET department students known that $28 \%$ student want to work as teachers or lecturers, $31 \%$ student want to be entrepreneurs, $28 \%$ student want to be employee in the company including media companies such as television and the remaining 13 $\%$ student plan as a freelance worker. The student's career choice Educational Administration study program is as follows. $35 \%$ student want to become entrepreneurs, $27 \%$ student work in the field of education, $16 \%$ student worked in banking, $22 \%$ student would like to work as an employee of the company. In the second option, $11.5 \%$ student who chose to work in the field of education, $15 \%$ student worked in banking, $20 \%$ student plan to become entrepreneurs and $53.5 \%$ student worked as managers and employees of the company,

Profile of student career choice of non formal education department are $13 \%$ student want to be non formal education tutors, $50 \%$ student want to be entrepreneur, $37 \%$ student want to be a civil servant and company.

The data from the focus group discussion with the student are, they have limited knowledge about some risk dan potential of Asean Economic Society. Educational profession is't major choice because they want to get freedom in career and doing their own work choice. Most of the student want to build their own business as their choice. Overview of the results of these studies demonstrate career adaptability and career planning and choice of teh student of faculty of education in facing the task of career development today and in the future, including to face and struggle the transition in the 
workplace and deal with and manage issues in the roles and duties of the job in which they live, both issues were small and simple to large and complex problem and cause traumatic effects still in the moderate category and still needs to be improved.

The profile above could support Savickas (2012) theori and many other career field researchers that put the adaptability career as one predictor of a person's career success. Referring to the view that this study could be used to explain and conduct the initial prediction sees opportunities faculty of education facukty of education student career success. From the research illustrates that overall faculty of education students have career adaptability to the medium category. Specifically, concern for careers, curiosity on the information and career development, career development and control in her confidence was also average middle category. Among the seven Department in faculty of education it was obvious that only the student's career adaptability Educational Administration study program are likely to be high, whereas career adaptability of students six other study programs tend to be moderate. Savickas (2012) explains that career adaptability required in social integration and achievement of career development tasks throughout the life span.

Generally it can be explained that the student of faculty of education student have medium career adaptability specially in career concern [4] and longterm orientation and a feeling of optimism as professional workers are also in the medium category. Though low concern can lead to pessimism career will be successful in the future. Meanwhile, the control of the student's career faculty of education also at the level of being. This means that efforts to improve the self-management through decision-making and responsibility for the future is still not optimal. career theory mentioned that student who lack of ability to control the career potential will cause some problems related to career decisions, they also have some difficulties to choose future career [5] Similarly, the curiosity in a career or career opportunities curiosity interpreted as a tendency to understand the environment and the latest information about careers. Career curiosity describe curiosity caused by a productive career exploration and the opportunity to realistically explore the educational and occupational information in the future (Flum \& Blustein, 2000; Patton \& Porfeli, 2007). The resut above figure that students' career curiosity need to enhance in order to help them fulfilling career development maximally.
Other findings are quite interesting from this study is the variety of career choices of students, which work in the field of education is the priority choice of student of Elementary Education department, Guidance and Counseling, and special education, but in the other study programs, such as non formal education, educational technology and school administration put educational profession as their second choice. Theye tent to interest in being entrepreneur, company employee or freelancer.

The results and findings of the study have implications for efforts to support career guidance for students. In the process of career exploration and achieve career adaptability, students need guidance in improving career readiness. Efforts to enhance career adaptabiliy through career guidance is necessary so that they achieve career success and will rise their participation in the development in Indonesia and ready to compete in the context of Asean Economic Society.

\section{CONCLUSIONS AND RECOMMENDATIONS}

This study showed that students' career adaptability; career concern, career curiosity, career control, and career confidence tends to catogarize in the medium level. Among the student in seven departments of faculty of education only the students of school administration department who has high level of career adaptability. In general, students of faculty of education choose some professions in educational field as the first choice, but in their own style. A unique finding is, enterpreuner has become new favourite career choice. The results of study suggested to (1) academics and researchers in the field of career counseling for assessing the adaptability of a career on the subject of wider design correlational research or qualitative (2) practitioners Guidance and Counseling in Higher Education, especially at UM, in order to provide career guidance program to improve the career adaptability of student early.

\section{REFERENCES}

[1] Gibson, L. R dan Mitchell, M. H. 2006. Introduction to CareerCounseling for the $21^{s t}$ Century. Columbus Ohio: Pearson Merryl Prentice Hall.

[2] Herr, E. L. dan Cramer, S.H. 1984. Career Guidance and Counseling Through the Life 
Span: Sistematic Approaches. Toronto: Little, Brown \& Company.

[3] Savickas. M.L. 1997. Career Adaptability; a Integratif Construct for Life Span and Life Space Theory. The Career Development Quarterly. Vol 45, Maret 1997

[4] Yousefi, Z., Abedi, M., Baghban, I. 2011. Personal and Situational Variables, and Career Concerns: Predicting Career Adaptability in Young Adults. The Spanish Journal of Psychology, Vol. 14 No. 1, 263271

[5] Pordelan, I., Abedi, M.R., Baghban, I., Nilforooshan, P. 2014. Comparison of Career Adaptability in Employed and Unemployed Undergraduates of Isfahan University. International Journal of Psychology and Behavioral Research. Vol., 3(2), 129-134.

[6] Hirschi, A. 2009.. Career adaptability development in adolescence: Multiple predictors and effect on sense of power and life satisfaction. Journal of Vocational Behavior, 74(2), 145-155.

[7] Hirschi, A. (2012). The Career Resources Model: an Integrative Framework for Career Counsellors. British Journal of Guidance \& Counselling, 40(4), 369-383.

[8] Bartley, D. F. and Robitschek, C. 2000. Career Exploration: A Multivariate Analysis of Predictors. Journal of Vocational Behavior Vol.56, halaman 6381

[9] Borg, W. R dan Gall, M.D. 1983. Educational Research an Introduction. Boston: Allyn and Bacon.

[10]Borg, W. R dan Gall, M.D. 2003. Educational Research an Introduction. Boston: Allyn and Bacon.

[11]Brown, Duane \& Brooks, Linda and Associates. 1984. Career Choice and Development. California: Jossey-Bass Inc.

[12] Crites, J.O. 1981. Career Counseling Models, Methods, and Materials. New York: McGraw-Hill, Inc.

[13] Gregory, R.J. 2011. Psychological Testing History, Principles, and Aplsication ( $6^{\text {th }}$ $E d)$. Boston: Allyn and Bacon.

[14] Harkness, H. 2004. A model for your future Career: You're On Your Own. Career planning and adult development journal Volume 24, number 2

[15] Muslihati. 2013. Ancangan Strategi Perencanaan Karier "KAMIL" dalam peminatan di SMA. Makalah dalam
Coursesing Seminar Nasional Program

Peminatan dalam Kurikulum 2013. Malang: Jurusan Bimbingan dan Konseling, Universitas Negeri Malang.

[16] Muslihati. 2014. Nilai-nilai kerja Budaya Madura dan Kontribusinya pada Subjective Well-being. Jurnal Humaniora. P3SHOK. LP2M. Universitas Negeri Malang.

[17] www.asean.org. 2014. Menjelang Masyarakat Ekononi ASEAN. Diakses pada tanggal 15 April 2015. 